\title{
Effect of Process and Service Conditions on TLP-Bonded Components with (Ag,Ni-)Sn Interlayer Combinations
}

\author{
ADRIAN LIS ${ }^{1}$ and CHRISTIAN LEINENBACH ${ }^{1,2}$ \\ 1.-Empa, Swiss Federal Laboratories for Materials Science and Technology, Laboratory for \\ Joining Technologies and Corrosion, Ueberlandstrasse 129, 8600 Dübendorf, Switzerland. \\ 2.-e-mail: christian.leinenbach@empa.ch
}

Transient liquid phase (TLP) bonding of $\mathrm{Cu}$ substrates was conducted with interlayer systems with the stacking sequences $\mathrm{Ag}-\mathrm{Sn}-\mathrm{Ag}$ (samples $\mathrm{A}$ ), Ni$\mathrm{Sn}-\mathrm{Ni}$ (samples B), and combined Ag-Sn-Ni (samples C). Because of the low mismatch of the coefficients of thermal expansion, characteristics of the TLP process and mechanical and thermal behavior of TLP-bonded samples could be investigated without interference from thermally induced residual stresses. An ideal process temperature of $300^{\circ} \mathrm{C}$, at which the number of pores was lowest, was identified for all three layer systems. It was verified experimentally that formation of pores resulted from volume contraction during isothermal solidification of liquid Sn into intermetallic compounds (IMC). Temperature and interlayer-dependent growth characteristics of IMC accounted for the increasing size and number of defects with increasing process temperature and for different defect positions. The shear strength was measured to be $60.4 \mathrm{MPa}, 27.4 \mathrm{MPa}$, and $40.7 \mathrm{MPa}$ for samples $\mathrm{A}, \mathrm{B}$, and $\mathrm{C}$, respectively, and ductile fracture features were observed for $\mathrm{Ag}_{3} \mathrm{Sn}$ IMC compared with the purely brittle behavior of $\mathrm{Ni}_{3} \mathrm{Sn}_{4}$ IMC. Excellent thermal stability for all three layer systems was confirmed during long-term annealing at $200^{\circ} \mathrm{C}$ for up to $1200 \mathrm{~h}$, whereas at $300^{\circ} \mathrm{C}$ the microstructure was driven toward Ag-Sn solid solution, accompanied by $\mathrm{Cu}$ diffusion from the substrate along grain boundaries and $\mathrm{Cu}_{3} \mathrm{Sn}$ IMC formation (A), and toward Ni-rich IMC phases (B). Combined IMC interlayers (C) tended to be transformed into Ni-based IMC when held at $300^{\circ} \mathrm{C}$; intermixing into $(\mathrm{Ni}, \mathrm{Cu})_{3} \mathrm{Sn}$ was accompanied by pore formation.

Key words: TLP bonding, microstructure, defect formation, shear strength, annealing

\section{INTRODUCTION}

Power module packaging faces demanding challenges because of harsh restrictions on Pb-based solder alloys and the increasing tendency to miniaturize devices by introducing $\mathrm{SiC}$ technology. Replacement of Si semiconductors has the potential to result in greater efficiency, because $\mathrm{SiC}$ is much more temperature-resistant, so power modules can theoretically operate at higher temperatures and active cooling systems or heat sinks can be reduced

(Received March 12, 2015; accepted August 10, 2015;

published online August 28, 2015) or even avoided. ${ }^{1,2}$ In this context, transient liquid phase (TLP) bonding has been identified as a promising low-temperature joining technique which satisfies the above mentioned demands of chip packaging.

Low-temperature TLP bonding is achieved by placing a sandwiched interlayer system consisting of a high-melting-point material, i.e. $\mathrm{Cu}, \mathrm{Ni}, \mathrm{Ag}$, or $\mathrm{Au}$, and a low-melting-point material, i.e. Sn or In, between the two components to be joined. After melting of the interlayer, interfacial formation of intermetallic compounds (IMC) starts and isothermal solidification of the connection proceeds until 
the liquid metal is fully consumed. This diffusioncontrolled mechanism leads to the exceptional feature of TLP bonding that the remelting temperature of the joint is higher than the process temperature. ${ }^{3}$

However, before TLP bonding can be reliably implemented in applications, fundamental research is required to enable understanding and control of the joining process and for determination of the durability and limitations during operating conditions. Many researchers have investigated the growth kinetics, diffusion mechanisms, and morphological characteristics of formation of IMC from different layer systems, e.g. $\mathrm{Cu}-\mathrm{Sn},{ }^{4-7} \mathrm{Ni}-\mathrm{Sn},{ }^{4,8-12}$ $\mathrm{Ag}-\mathrm{Sn},{ }^{13-18}$ or In-based systems. ${ }^{19-23}$ Schaefer et al. ${ }^{6}$ developed a model in which grain boundary (GB) diffusion was identified as the factor responsible for the observed $t^{1 / 3}$ growth kinetics of the $\mathrm{Cu}-$ Sn IMC layer with scallop-like morphology. $\mathrm{Li}$ et al. ${ }^{14}$ used sandwiched $\mathrm{Ag}-\mathrm{Sn}-\mathrm{Ag}$ structures to determine the kinetics of scallop-like $\mathrm{Ag}_{3} \mathrm{Sn}$ IMC growth, and confirmed the $t^{1 / 3}$-dependence for temperatures of $260^{\circ} \mathrm{C}, 300^{\circ} \mathrm{C}$, and $340^{\circ} \mathrm{C}$ and holding times from 5 min to 475 min. Gur and Bamberger ${ }^{10}$ identified a microstructural transition zone (MTZ) which was explained by the simultaneous and opposite growth of coarse-grained $\mathrm{Ni}_{3} \mathrm{Sn}_{4}$ IMC toward the $\mathrm{Sn}$ side and fine-grained $\mathrm{Ni}_{3} \mathrm{Sn}_{4}$ toward the $\mathrm{Ni}$ substrate. The IMC scallops observed at $500^{\circ} \mathrm{C}$ were shown to transform into elongated faceted grains compared with reaction at lower temperatures of $400^{\circ} \mathrm{C}$ and $350^{\circ} \mathrm{C}$. In a different approach, Görlich et al. ${ }^{19}$ used near-isothermal experimental conditions $\left(250^{\circ} \mathrm{C}\right)$ from $30 \mathrm{~s}$ to 7 days of holding time and observed that $\mathrm{Ni}_{3} \mathrm{Sn}_{4}$ IMC growth kinetics were best fitted by a cubic growth law for periods up to $3 \mathrm{~min}$ but followed a parabolic function for longer holding times. Needle-like $\mathrm{Ni}_{3} \mathrm{Sn}_{4}$ IMC at the Ni-Sn interface and detached polygonal IMC crystals were observed, in good agreement to the work of Bader et al. ${ }^{8}$ These fundamental studies aided understanding of the effect of such conditions as temperature, time, and heating rate, and the grain structure and chemical composition of the layers on IMC growth behavior during TLP bonding.

Effort has also been devoted to characterization of TLP bonded chips to metallic substrate materials when a high mismatch between the coefficients of thermal expansion (CTE) strongly affects the microstructural, ${ }^{24-26}$ mechanical, ${ }^{27-29}$ or electrical properties ${ }^{30}$ after processing, annealing, or thermal cycling.

However, the characteristics of the TLP process and the thermal stability of TLP bonded components without or with a negligible CTE mismatch have hardly been investigated. Bosco et al. ${ }^{31}$ TLP bonded $\mathrm{Cu}$ substrates with coated Sn interlayers at $550^{\circ} \mathrm{C}$ and derived a model for defect formation which predicted that a minimum thickness of $\mathrm{Sn}$ is required to minimize defects. This condition ensures that a continuous Sn layer is left after heating and the corresponding solid-state formation of $\mathrm{Cu}-\mathrm{Sn}$ IMC before the melting point of $\mathrm{Sn}$ is exceeded and the solid-liquid reaction starts. While useful, the proposed model seems to be valid only for coated interlayers and the process temperature investigated is much too high for chip packaging. In followup work, ${ }^{32}$ they observed that heat treatment for $30 \mathrm{~min}$ at $550^{\circ} \mathrm{C}$ improved the initial bending strength of $\mathrm{Cu}-\mathrm{Sn}$ TLP bonded rod specimens from $300 \mathrm{MPa}$ to $400 \mathrm{MPa}$, because of a change in microstructure from pure IMC to a mixture of IMC and $\mathrm{Cu}-\mathrm{Sn}$ solid solution. Gollas et al. ${ }^{33}$ used TLPbonded $\mathrm{Cu}$ substrates with $\mathrm{Ag}-\mathrm{Sn} / \mathrm{In}-\mathrm{Ag}$ interlayers for high-temperature in situ x-ray diffraction (XRD) measurements during annealing at $320^{\circ} \mathrm{C}$. They tracked the transformation of $\mathrm{Ag}_{3} \mathrm{Sn}$ into $\mathrm{Ag}_{5} \mathrm{Sn}$ after $40 \mathrm{~min}$ and subsequently into $\mathrm{Ag}-\mathrm{Sn}$ solid solution after $480 \mathrm{~min}$ of holding time. Chung et al. ${ }^{34}$ proposed the use of $\mathrm{Sn} 2.4 \mathrm{Ag}$ solder instead of pure $\mathrm{Sn}$ to join Ni-coated substrates. Voids within the $\mathrm{Ni}_{3} \mathrm{Sn}_{4}$ IMC layer were filled by $\mathrm{Ag}_{3} \mathrm{Sn}$ IMC in long-term solid-state reactions. Similarly, a patent by Chang et al. ${ }^{35}$ claims elimination of voids within the IMC layer as a result of formation of a dualphase IMC layer by applying interlayers between two substrates with different metallization.

In this work, three different interlayer systems, $\mathrm{Ag}-\mathrm{Sn}-\mathrm{Ag}, \mathrm{Ni}-\mathrm{Sn}-\mathrm{Ni}$, and combined layers of $\mathrm{Ag}-$ $\mathrm{Sn}-\mathrm{Ni}$, were investigated by use of the same methodology. Microstructural analysis of TLP-bonded $\mathrm{Cu}$ specimens was performed to find the optimum process conditions for chip packaging $\left(T_{\max }=350^{\circ} \mathrm{C}\right)$ from the perspective of both process kinetics and the appearance of joining defects. General and interlayer-dependent mechanisms for defect formation, mechanical shear strength, and failure behavior are of interest for TLP-bonded samples with the three interlayer systems. Nearservice conditions on TLP joints were simulated by annealing experiments at $200^{\circ} \mathrm{C}$ and $300^{\circ} \mathrm{C}$ while microstructural changes were monitored over time.

\section{EXPERIMENTAL}

Two $\mathrm{Cu}$ plates with the dimensions $110 \mathrm{~mm} \times 60 \mathrm{~mm} \times 4 \mathrm{~mm}$ were electroplated with $14 \mu \mathrm{m} \mathrm{Ag}$ and with $17 \mu \mathrm{m} \mathrm{Ni}$, respectively. After coating, both plates were cut into smaller $5 \mathrm{~mm} \times 5 \mathrm{~mm} \times 4 \mathrm{~mm}$ samples by electrical discharge machining (EDM) and the sharp sample edges were chamfered at an angle of $45^{\circ}$, which reduced the effective bonding area to $20.25 \mathrm{~mm}^{2}$ $(4.5 \mathrm{~mm} \times 4.5 \mathrm{~mm})$. Sn foil of thickness $8 \mu \mathrm{m}$ and purity $99.75 \%$ was used (Goodfellow Cambridge), to avoid solid-state reactions during heating which occur for coated interlayers, as discussed elsewhere. $^{31}$ The surface and bulk quality of the coated layers (after cutting and degreasing) and the Sn foil (as-delivered) were analyzed by x-ray photoelectron spectroscopy (XPS). A small amount of sulfate was found on the Ag coating because of contact with the 

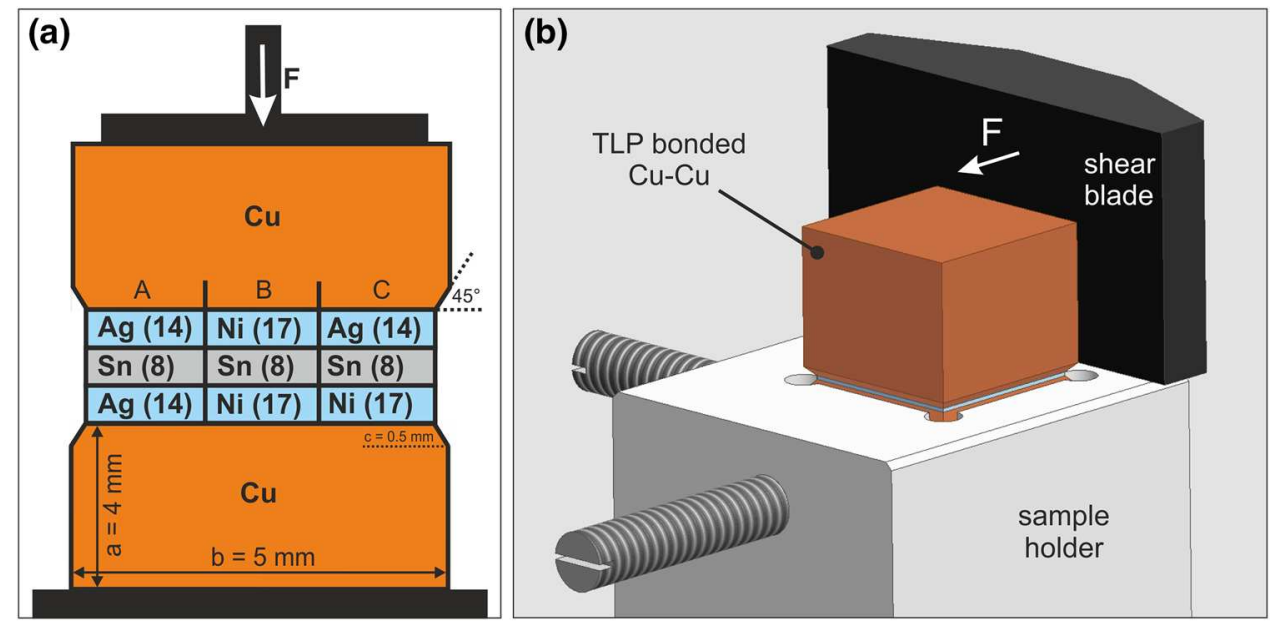

Fig. 1. (a) Schematic diagram of assembly of coated Cu substrates and Sn foil for TLP bonding (all values in brackets are in $\mu \mathrm{m}$ ); (b) shear test set up for TLP-bonded Cu substrates.

dielectric medium during EDM; no residues were observed on the surface of the Ni coating. The surface of the Sn foil was contaminated with reaction products containing $\mathrm{S}, \mathrm{P}$, and $\mathrm{Cr}$; an oxide layer of thickness $10 \mathrm{~nm}$ was also detected. To remove contaminants and oxides, Ag-coated $\mathrm{Cu}$ substrates and the $\mathrm{Sn}$ foil were dipped for seconds in $\mathrm{HNO}_{3}$ (5 vol.\%) and $\mathrm{HCl}$ (10 vol.\%), respectively. Substrates and foil were assembled in accordance with Fig. 1a to perform TLP bonding with $\mathrm{Ag}-\mathrm{Sn}-\mathrm{Ag}$ (samples A), Ni-Sn-Ni (samples B), and Ag-Sn-Ni (samples $\mathrm{C}$ ) interlayer combinations.

Investigations on combined interlayers are of interest for technical applications in which (different) as-delivered coatings may be used for TLP bonding instead of depositing additional layers and when the approaches discussed in Refs. 34 and 35 are applied. All joining experiments were conducted in a tube furnace system under an argon 6.0 shielding gas atmosphere while applying a bonding pressure of $0.3 \mathrm{MPa}$. A heating rate of $15 \% \mathrm{~min}$ was selected but slow cooling of approximately $2 \%$ min was used to minimize thermal gradients within the samples. The process temperature varied among $260^{\circ} \mathrm{C}, 300^{\circ} \mathrm{C}$, and $350^{\circ} \mathrm{C}$ and the isothermal holding time was adjusted in accordance with the IMC growth kinetics investigated in our previous work. ${ }^{15,36}$ The rate of consumption of $\mathrm{Sn}, z_{\mathrm{Sn}, \mathrm{con}}$, was determined as a function of temperature and time according to:

$$
\begin{gathered}
z_{\text {Sn }, \text { con }}(T, t)=\left[\left(\frac{\varphi}{\varphi+1}\right) \sqrt{k_{0} \exp \left(\frac{-Q}{R T}\right) \cdot t}\right] \\
=\left(\frac{\varphi}{\varphi+1}\right) \cdot z_{\mathrm{IMC}}(T, t)
\end{gathered}
$$

with

$$
\varphi=\frac{Y}{X} \cdot \frac{M(S n) / \rho(S n)}{M(B) / \rho(B)}
$$

where $\varphi$ is the transformation factor which describes how much Sn (in volume or thickness) is consumed by formation of an IMC layer $z_{\text {IMC }}$ of defined thickness. $M$ is the molar mass, $\rho$ is the density of Sn and base material B (Ag or Ni). $X$ and $Y$ are the stoichiometric atomic ratios of the forming IMC, e.g. $X$ is 3 and $Y$ is 4 for $\mathrm{Ni}_{3} \mathrm{Sn}_{4}$ IMC. $\mathrm{R}$ is the universal gas constant, $t$ is the time, and $T$ is the process temperature in Kelvin. The activation energy $Q$ with identical electroplated coatings was derived as $30.6 \mathrm{~kJ} / \mathrm{mol}$ for $\mathrm{Ag}_{3} \mathrm{Sn}$ IMC growth ${ }^{15}$ and $43.3 \mathrm{~kJ} / \mathrm{mol}$ for $\mathrm{Ni}_{3} \mathrm{Sn}_{4}$ IMC growth ${ }_{3}^{36}$ the proportionality constant $\mathrm{k}_{0}$ was $4.6 \times 10^{-7} \mathrm{~cm}^{2} / \mathrm{s}$ for the $\mathrm{Ag}-\mathrm{Sn}$ system and $4.93 \times 10^{-7} \mathrm{~cm}^{2} / \mathrm{s}$ for the Ni-Sn system. The holding time $t$ for TLP bonding can be calculated by transforming Eq. 1 and inserting the holding temperature $T$ and the required $\mathrm{Sn}$ consumption of $4 \mu \mathrm{m}$ (at both base metal-Sn interfaces). Calculation resulted in holding times of $80 \mathrm{~min}$ at $260^{\circ} \mathrm{C}, 60 \mathrm{~min}$ at $300^{\circ} \mathrm{C}$, and $45 \mathrm{~min}$ at $350^{\circ} \mathrm{C}$ for the three interlayer systems to fully consume the liquid Sn phase. These temperatures were selected because joining processes in high-power modules are limited to $350^{\circ} \mathrm{C}$, at which the semiconducting properties of $\mathrm{Si}$ and the consistency of polymeric insulators are not affected.

$\mathrm{Cu}$ was selected as substrate material to minimize thermally induced residual stresses after joining and to achieve rapid and homogeneous heating of the samples. After the TLP process, the samples were embedded in cold mounting resin and prepared metallographically by step-wise grinding and final polishing with silica suspension. The polished samples were subsequently treated by argon ion beam flat milling (Hitachi IM4000) to remove preparation artefacts, for example smearing between ductile interlayers. Microstructure was investigated by scanning electron microscopy (SEM; Hitachi S-3700 N) and energy-dispersive x-ray spectroscopy (EDS; EDAX Octane Pro). Mechanical 
shear strength was investigated for samples from series $\mathrm{A}, \mathrm{B}$, and $\mathrm{C}$ which had been TLP bonded at $300^{\circ} \mathrm{C}$, because of their small number of defects (shear test device by Walter and Bai). A sample holder, shown in Fig. 1b, was designed to guarantee ideal fixing and adjustment to a shear blade consisting of tungsten carbide (WC) and to apply the shear force $F$ directly above the TLP joint. The mean shear strength was determined from 7 measurements for every sample type. Overlaying bending moments $M$ on the joint during shear testing can be estimated for our set up by use of Eq. 3; the results are listed in Table I.

$$
M=F \cdot\left(\frac{a-c}{2}\right)
$$

Fractographic analysis by SEM and EDS was performed to determine failure mode and position. Furthermore, TLP-bonded samples A, B, and C with smallest number of defects, i.e. those joined at $300^{\circ} \mathrm{C}$, were subjected to isothermal annealing at temperatures of $200^{\circ} \mathrm{C}$ and $300^{\circ} \mathrm{C}$ for up to $1200 \mathrm{~h}$ of holding time in an air furnace (Nabertherm). Microstructural changes during annealing were analyzed by SEM and EDS on cross sections, as described above.

\section{RESULTS}

\section{TLP Bonding with Ag-Sn-Ag Interlayers}

\section{Phase Formation During TLP Bonding}

TLP bonding on samples $\mathrm{A}$ with $\mathrm{Ag}-\mathrm{Sn}-\mathrm{Ag}$ interlayers was performed at $300^{\circ} \mathrm{C}$ and $350^{\circ} \mathrm{C}$. At both temperatures, the process was interrupted after $1 \mathrm{~min}$ of dwell time to freeze an intermediate stage of $\mathrm{Ag}_{3} \mathrm{Sn} \mathrm{IMC} \mathrm{formation.} \mathrm{At} 300^{\circ} \mathrm{C}$, small and randomly distributed IMC scallops can be observed in Fig. 2a; similar larger scallops with an averaged lateral grain size of $10 \mu \mathrm{m}$ evolve when the temperature is increased to $350^{\circ} \mathrm{C}$, as shown in Fig. $2 \mathrm{~b}$. Some of these large scallops already reach the opposite reaction front line after short holding time of $1 \mathrm{~min}$. After full consumption of Sn, TLP joints produced at $350^{\circ} \mathrm{C}$ contain a large number of pores within the IMC layer (Fig. 2d) whereas a lower process temperature of $300^{\circ} \mathrm{C}$ leads to significant reduction of defect size and amount, as shown in Fig. 2b. EDS measurements revealed a higher con- centration of $\mathrm{Sn}$ in the $\mathrm{Ag}$ layers after processing at $350^{\circ} \mathrm{C}$ than after processing at $300^{\circ} \mathrm{C}$, i.e. approximately 4 at.\% and approximately 2 at.\%, respectively. $\mathrm{Ag}$ can be distinguished from the $\mathrm{Ag}_{3} \mathrm{Sn}$ IMC by the different grain size; the Ag layers have a much finer grain structure compared with the sandwiched $\mathrm{Ag}_{3} \mathrm{Sn}$ IMC layer between them. Shear tests were performed on samples TLP bonded at $300^{\circ} \mathrm{C}$ which contain significantly fewer defects. The measured values are summarized in Table I. The mean measured external shear force $F_{\text {mean }}$ was $1222 \pm 141 \mathrm{~N}$; this corresponds to a mean shear strength, $\tau_{\text {mean }}$, of $60.4 \pm 7 \mathrm{MPa}$ when the effective bonding area is considered. Pronounced shear marks, shown in Fig. 3a, were observed all over the fracture surface, indicating the force direction parallel to the joint. In a small volume at the end opposite to that of shear force introduction, plastic deformation marks were found, as shown in Fig. 3b. The tilt angle represents the force direction, and suggests a small fraction of tensile loading. This is most likely to be related to crack opening immediately before fracture so that the top substrate slightly tilts and the applied force no longer acts parallel to the joint. Only cohesive fracture within the $\mathrm{Ag}_{3} \mathrm{Sn}$ IMC layer was observed.

\section{Phase Formation During Annealing}

Long-term annealing was performed on samples A bonded at a processing temperature of $300^{\circ} \mathrm{C}$. After annealing at $200^{\circ} \mathrm{C}$ for $400 \mathrm{~h}$, the concentration of Sn in the surrounding Ag layers increased to 4 at.\% on average. After $1200 \mathrm{~h}, \mathrm{EDS}$ measurements confirmed that 7 at.\% Sn had dissolved in the $\mathrm{Ag}$ layers. According to the binary $\mathrm{Ag}-\mathrm{Sn}$ phase diagram, the maximum solubility of $\mathrm{Sn}$ in the fcc $\mathrm{Ag}$ crystal lattice is approximately 10 at.\% between $200^{\circ} \mathrm{C}$ and $400^{\circ} \mathrm{C}$.

Changes in microstructure after isothermal annealing at $300^{\circ} \mathrm{C}$ for $400 \mathrm{~h}$ are shown in Fig. 4 . Sn had dissolved in the Ag layers and reached its solid solution concentration of approximately 10 at. $\%$. The $\mathrm{Ag}_{3} \mathrm{Sn}$ and $\mathrm{Ag}$ layers still differ in grain size, as depicted in Fig. 4a. When the BSE phase contrast was strongly amplified, formation of an additional phase, i.e. $\mathrm{Cu}_{3} \mathrm{Sn}$, was revealed (Fig. $4 \mathrm{~b}$ ); it was equally distributed within the $\mathrm{Ag}_{3} \mathrm{Sn}$ and $\mathrm{Ag}$ layers. The volume fraction of $\mathrm{Cu}_{3} \mathrm{Sn}$ in the surrounding $\mathrm{Ag}$

Table I. Summary of shear test results for samples A, B, and C

\begin{tabular}{|c|c|c|c|c|c|c|c|}
\hline Sample & $\boldsymbol{F}_{\text {mean }}(\mathbf{N})$ & SD (force) (N) & $\sigma_{\text {mean }}(\mathrm{MPa})$ & SD (stress) (MPa) & $M_{\text {mean }}(\mathrm{Nm})$ & $\sigma_{\max }(\mathrm{MPa})$ & $\sigma_{\min }(\mathrm{MPa})$ \\
\hline $\begin{array}{l}\mathrm{A} \\
\mathrm{Ag}-\mathrm{Sn}-\mathrm{Ag}\end{array}$ & 1222 & 141 & 60.4 & 7 & 2.14 & 64.5 & 49.1 \\
\hline & 554 & 130 & 27.4 & 6.4 & 0.97 & 33.3 & 19.5 \\
\hline $\begin{array}{l}\mathrm{C} \\
\mathrm{Ag}-\mathrm{Sn}-\mathrm{Ni}\end{array}$ & 825 & 318 & 40.7 & 13.7 & 1.44 & 59.7 & 24.2 \\
\hline
\end{tabular}




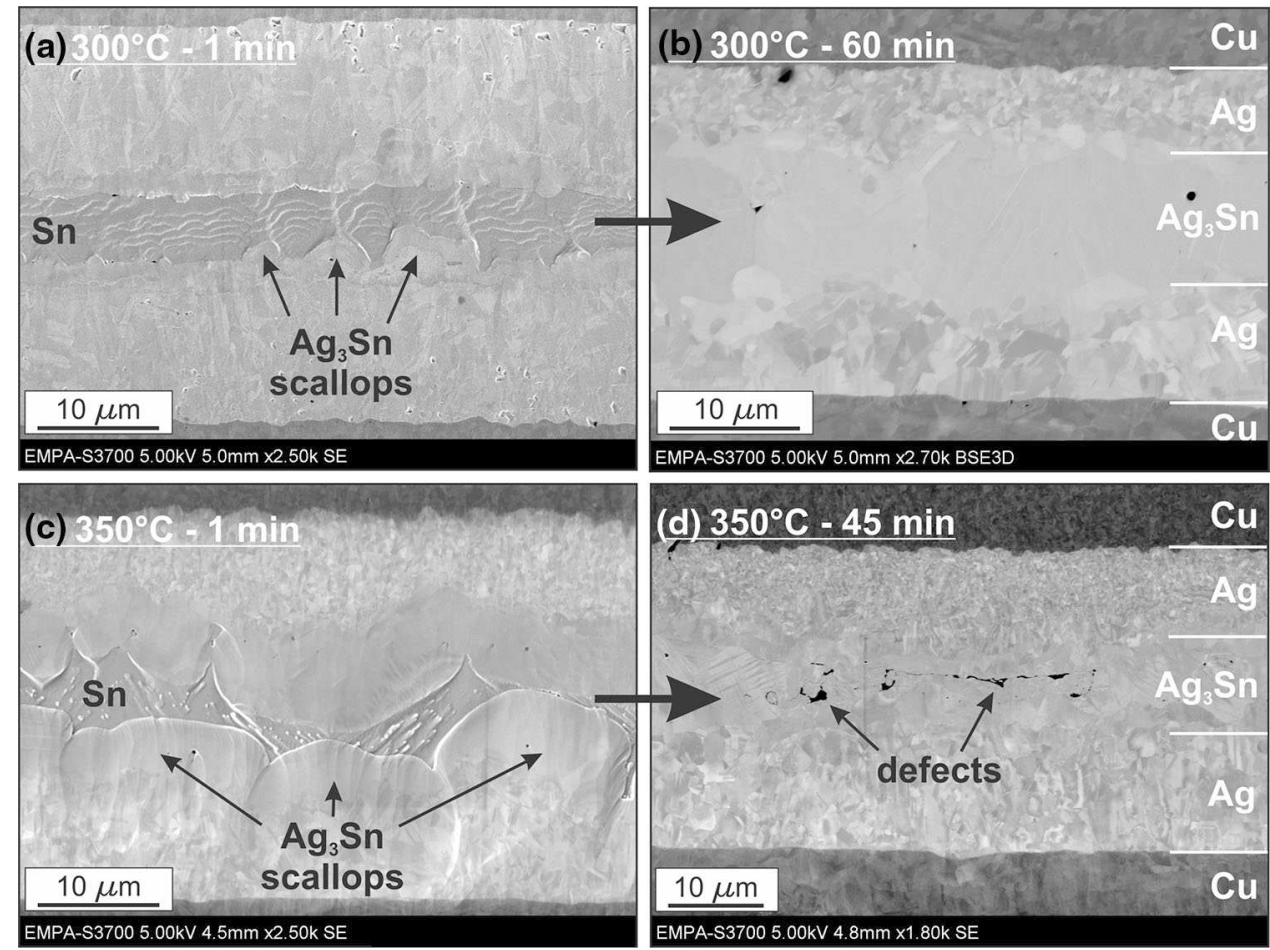

Fig. 2. TLP bonding of samples $\mathrm{A}$ at $300^{\circ} \mathrm{C}$ for (a) $1 \mathrm{~min}$ and (b) $60 \mathrm{~min}$, and at $350^{\circ} \mathrm{C}$ for (c) $1 \mathrm{~min}$ and (d) $45 \mathrm{~min}$.
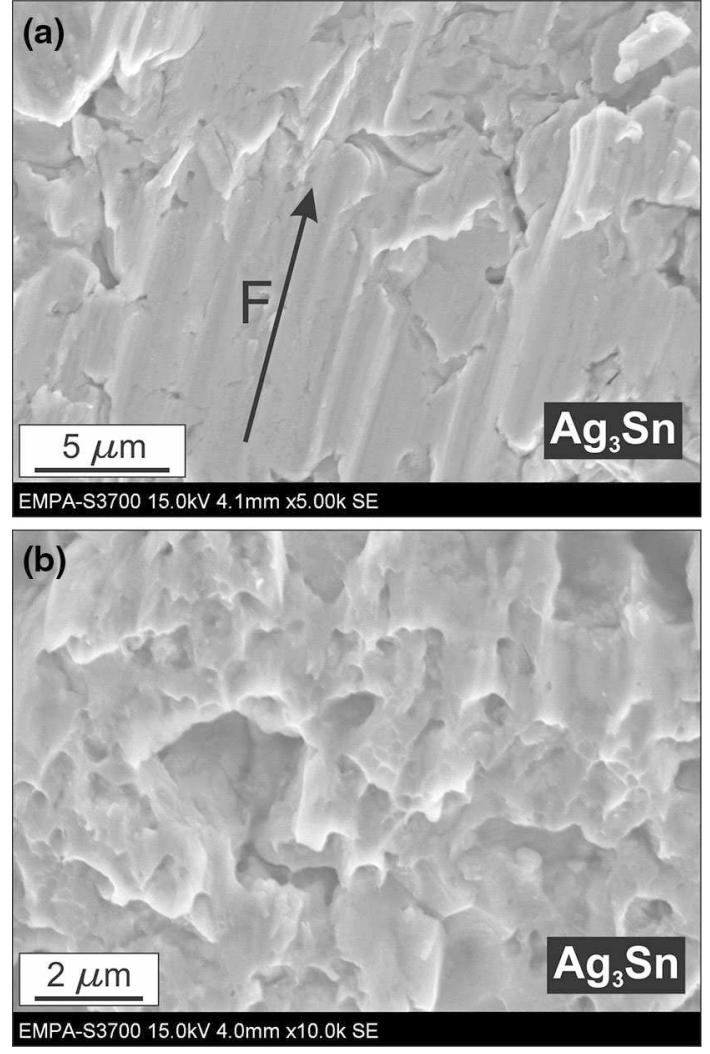

Fig. 3. Top view of fracture surface of samples $A$ with (a) shear marks as the predominant feature and (b) dimples in a small area at the end opposite to that of shear force introduction. and $\mathrm{Ag}_{3} \mathrm{Sn}$ matrix was measured from the phase contrast in the binary image as 3.8 vol.\%. $\mathrm{Cu}_{3} \mathrm{Sn}$ IMC formation evolves along grain boundaries which leads to their elongated shape. Diffusion rates of $\mathrm{Cu}$ into both $\mathrm{Ag}$ and $\mathrm{Ag}_{3} \mathrm{Sn}$ are sufficiently high at $300^{\circ} \mathrm{C}$ to cross the layered structure whereas at $200^{\circ} \mathrm{C}$ this effect was not observed.

Diffusion of $\mathrm{Cu}$ continues when annealing is continued for $1200 \mathrm{~h}$; this results in the growth of existing $\mathrm{Cu}_{3} \mathrm{Sn}$ particles and the nucleation of new $\mathrm{Cu}_{3} \mathrm{Sn}$ particles. Figure $4 \mathrm{c}$ and $\mathrm{d}$ show the significant volumetric increase of $\mathrm{Cu}_{3} \mathrm{Sn}$ fraction to 14.4 vol.\%. The difference between the grain sizes of $\mathrm{Ag}$ and $\mathrm{Ag}_{3} \mathrm{Sn}$ has vanished in Fig. 4c, and EDS measurements confirmed that the $\mathrm{Cu}_{3}$ Sn IMC particles are embedded in a matrix of $\mathrm{Ag}-\mathrm{Sn}$ solid solution containing 10 at.\% of Sn.

\section{TLP Bonding with Ni-Sn-Ni Interlayers}

\section{Phase Formation During TLP Bonding}

TLP bonding for series $\mathrm{B}$ was performed with $\mathrm{Ni}-$ $\mathrm{Sn}-\mathrm{Ni}$ interlayers. TLP-bonded samples obtained at $260^{\circ} \mathrm{C}$ in Fig. 5a and at $300^{\circ} \mathrm{C}$ in Fig. 5b have similar microstructure. Characteristic defects form within the $\mathrm{Ni}_{3} \mathrm{Sn}_{4}$ IMC layer, with pores positioned at a more or less constant distance of $1 \mu \mathrm{m}$ from the $\mathrm{Ni}-\mathrm{Ni}_{3} \mathrm{Sn}_{4}$ interface, leading to the formation of two defect planes. Interestingly, no defects could be observed along the bond center line. However, if the process temperature is increased to $350^{\circ} \mathrm{C}$, large 

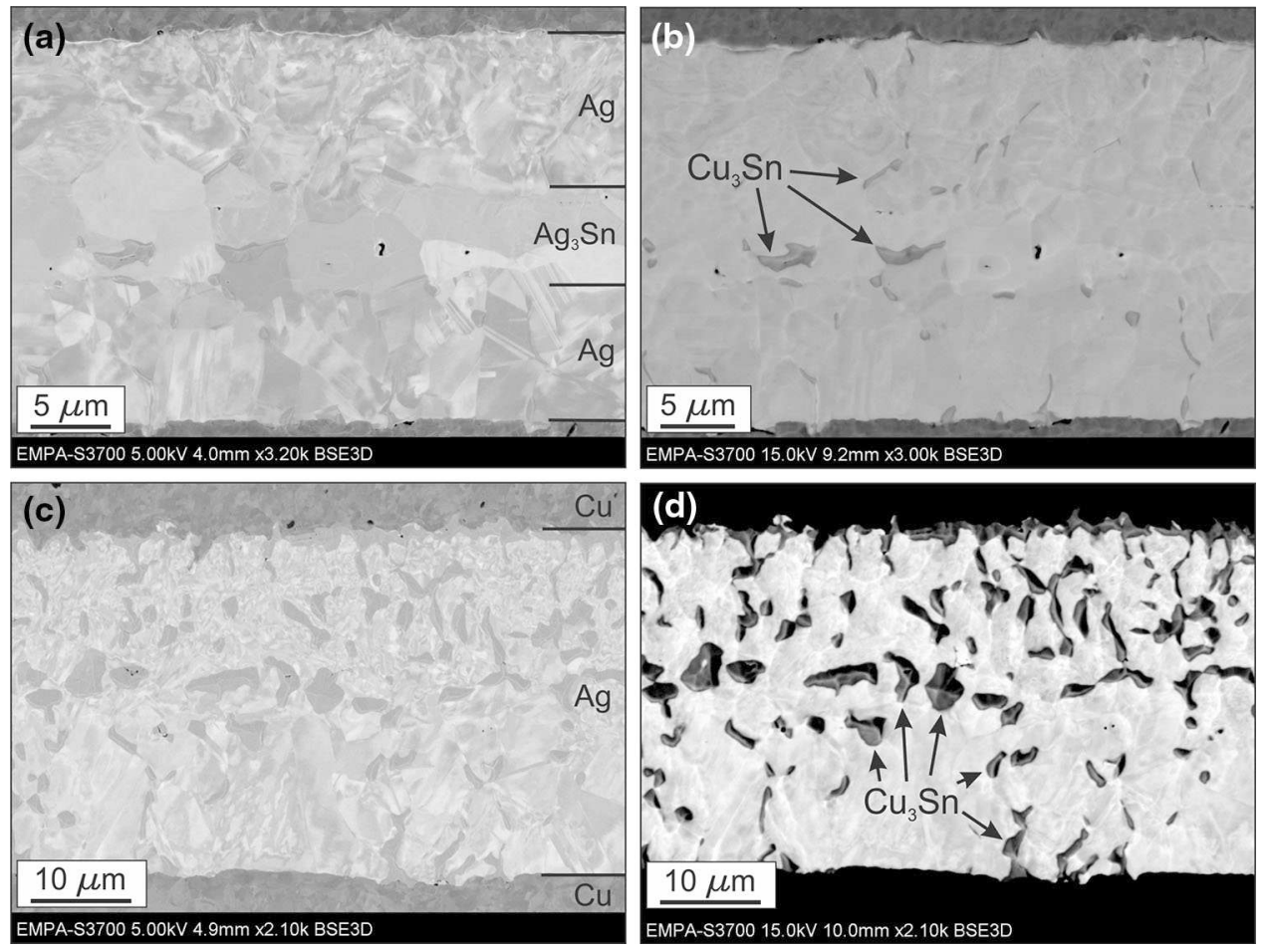

Fig. 4. TLP bonded microstructure with $\mathrm{Ag}-\mathrm{Ag}_{3} \mathrm{Sn}-\mathrm{Ag}$ during annealing at $300^{\circ} \mathrm{C}$, as grain structure image after (a) $400 \mathrm{~h}$ and (c) $1200 \mathrm{~h}$, and as phase-contrast image after (b) $400 \mathrm{~h}$ and (d) $1200 \mathrm{~h}$.

defects appear in the central part of the TLP-bonded samples, as is apparent in Fig. 5c.

A mean shear strength of $27.4 \pm 6.4 \mathrm{MPa}$ was measured for samples bonded at $300^{\circ} \mathrm{C}$, i.e. significantly lower than for samples A. The fracture surface shown in Fig. 6 confirms that the failure behavior is purely brittle and occurs within the $\mathrm{Ni}_{3} \mathrm{Sn}_{4}$ IMC layer at one of the defect planes. Needle-like IMC structures can be detected, with regularly distributed holes which represent the pores already viewed during the investigation of microstructure (Fig. 5b).

\section{Phase Formation During Annealing}

Samples B for annealing experiments with $\mathrm{Ni}-$ $\mathrm{Ni}_{3} \mathrm{Sn}_{4}-\mathrm{Ni}$ interlayers were TLP-bonded at $300^{\circ} \mathrm{C}$ for $60 \mathrm{~min}$; the microstructure is shown in Fig. 5b. At $200^{\circ} \mathrm{C}$, no changes of the microstructure could be observed after isothermal annealing for up to $1200 \mathrm{~h}$

When the annealing temperature was increased to $300^{\circ} \mathrm{C}$, formation of a $\mathrm{Ni}_{3} \mathrm{Sn}_{2}$ layer $1 \mu \mathrm{m}$ thick was observed at the initial $\mathrm{Ni}-\mathrm{Ni}_{3} \mathrm{Sn}_{4}$ interface after $400 \mathrm{~h}$ of holding time. This is in agreement with the $\mathrm{Ni}-\mathrm{Sn}$ binary phase diagram which predicts the $\mathrm{Ni}_{3} \mathrm{Sn}_{2}$ phase when moving from the Sn-rich side toward the Ni-rich side. The microstructure of these samples is shown in Fig. 7a, in which a slight BSE contrast between $\mathrm{Ni}_{3} \mathrm{Sn}_{4}$ and $\mathrm{Ni}_{3} \mathrm{Sn}_{2}$ is visible. The defect size and amount is remarkably reduced compared with the as-bonded samples (Fig. 4b).
Therefore, submicron-sized pores appear at the Ni$\mathrm{Ni}_{3} \mathrm{Sn}_{2}$ interface.

With a longer annealing time of $1200 \mathrm{~h}$, the thickness of the $\mathrm{Ni}_{3} \mathrm{Sn}_{2}$ layers approximately doubles and reaches a mean value of $2 \mu \mathrm{m}$. Simultaneously, $\mathrm{Ni}_{3} \mathrm{Sn}$ layers of averaged thickness $0.75 \mu \mathrm{m}$ form at the initial $\mathrm{Ni}-\mathrm{Ni}_{3} \mathrm{Sn}_{2}$ interfaces. Although the $\mathrm{Ni}_{3} \mathrm{Sn}$ layer grows more slowly than the $\mathrm{Ni}_{3} \mathrm{Sn}_{2}$ layer, $\mathrm{Ni}$ atoms can still diffuse into $\mathrm{Ni}_{3} \mathrm{Sn}_{2}$ and the system tends to form the final IMC phase in accordance with the binary Ni-Sn phase diagram. The corresponding microstructure is shown in Fig. 7b, in which the single layers are distinguished by adjustment of the BSE phase contrast. Pore size and the number of pores in the IMC layer are slightly reduced compared with the samples annealed for $400 \mathrm{~h}$. The electroplated Ni layer acts as an effective diffusion barrier for $\mathrm{Cu}$ atoms from the substrate material under these experimental conditions, because $\mathrm{Cu}-\mathrm{Sn} \mathrm{IMC}$ did not appear and $\mathrm{Cu}$ was not detected anywhere in the interlayer system (in contrast with samples A with Ag layers, as discussed in the section "Phase Formation During Annealing").

\section{TLP Bonding with Ag-Sn-Ni Combined Inter- layers}

\section{Phase Formation During TLP Bonding}

As is apparent from Fig. $8 \mathrm{a}$ and b, holding isothermal at $260^{\circ} \mathrm{C}$ for $80 \mathrm{~min}$ was not sufficient to 

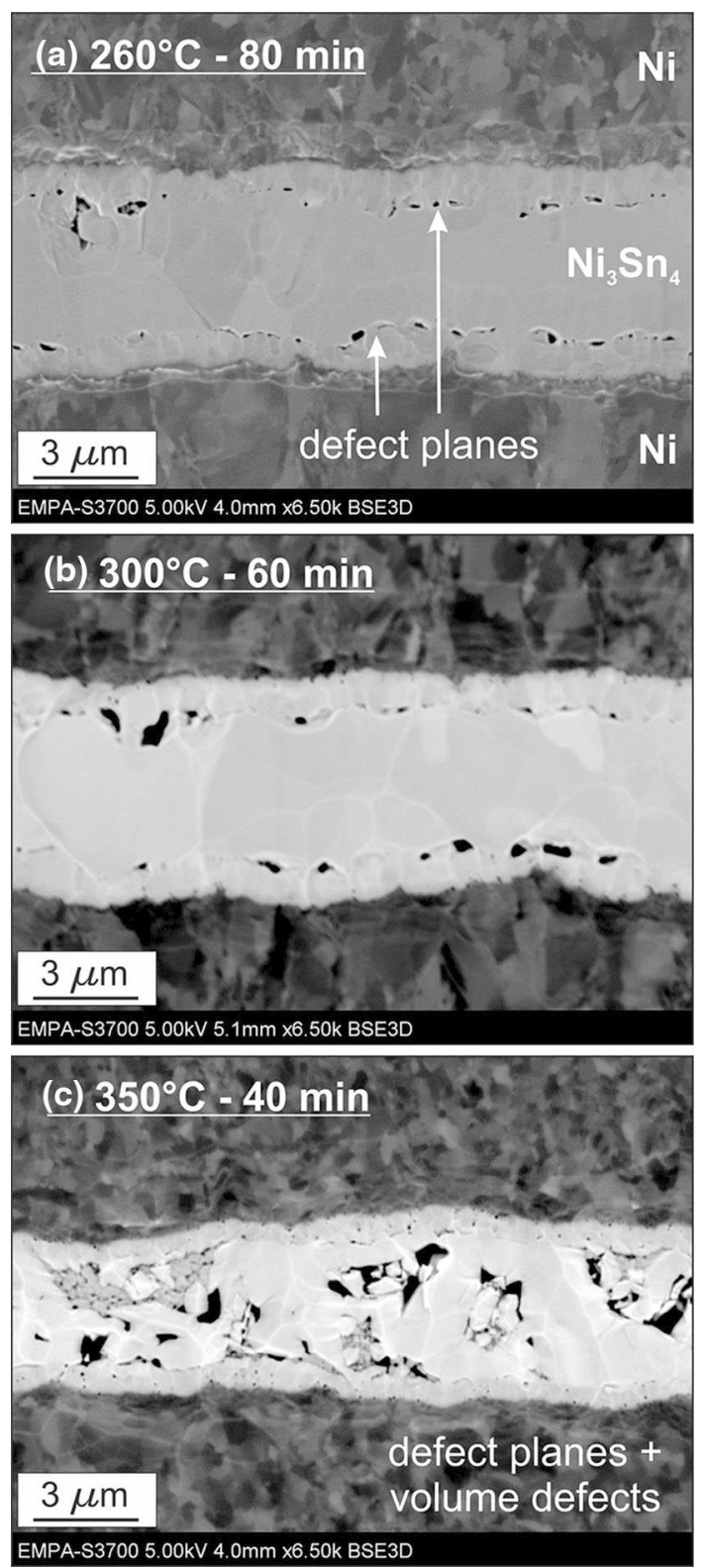

Fig. 5. TLP bonding of samples $B$ at (a) $260^{\circ} \mathrm{C}$, (b) $300^{\circ} \mathrm{C}$, and (c) $350^{\circ} \mathrm{C}$.

completely transform the liquid Sn layer into IMC, although complete transformation was expected according to Eq. 1. Characteristic features of $\mathrm{Ag}_{3} \mathrm{Sn}$ and $\mathrm{Ni}_{3} \mathrm{Sn}_{4}$ IMC morphology can be seen: the $\mathrm{Ni}_{3} \mathrm{Sn}_{4}$ IMC layer at the $\mathrm{Ni}$ interface grows with elongated and faceted structures whereas the $\mathrm{Ag}_{3} \mathrm{Sn}$ phase forms scallop-like IMC. $\mathrm{Ni}_{3} \mathrm{Sn}_{4}$ IMC islands are embedded in the remaining $\mathrm{Sn}$ and detached from the needle-shaped IMC layer below. It can be remarked that these IMC islands hinder growth of $\mathrm{Ag}_{3} \mathrm{Sn}$ scallops, as indicated at Pos. 1 and Pos. 2. The scallops are forced to grow around the $\mathrm{Ni}_{3} \mathrm{Sn}_{4}$ IMC islands; this results in a change of their welldefined scallop-like shape.

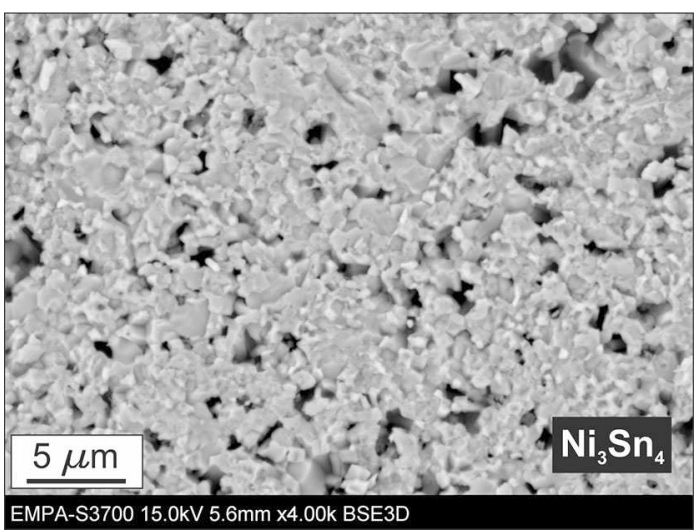

Fig. 6. Top view on fracture surface of samples B.
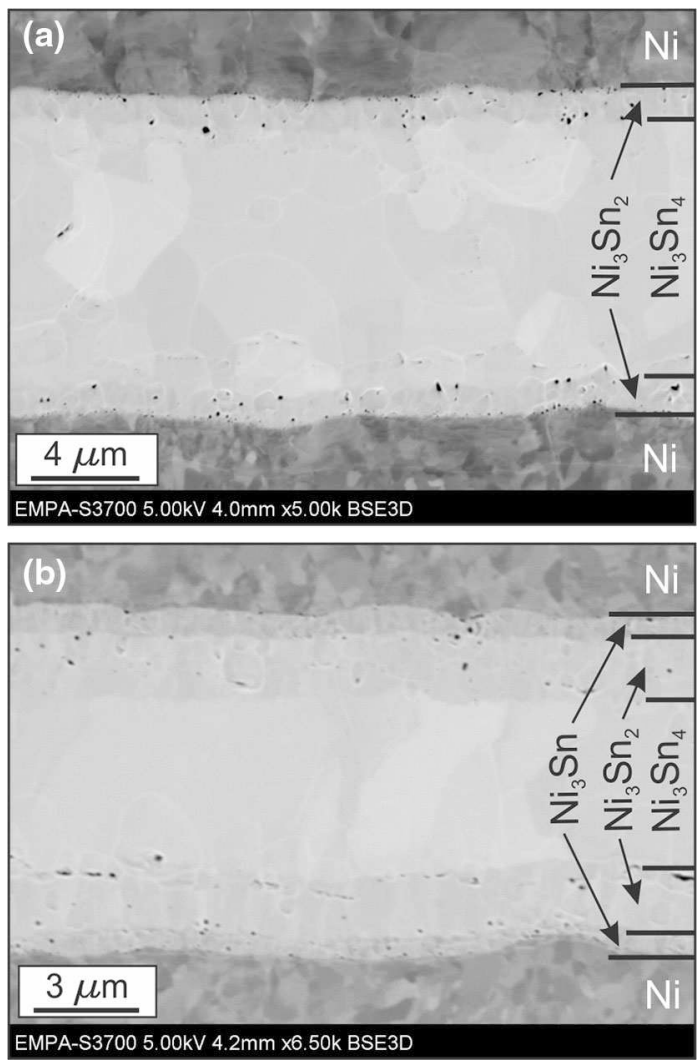

Fig. 7. TLP bonded microstructure with $\mathrm{Ni}-\mathrm{Sn}-\mathrm{Ni}$ after annealing at $300^{\circ} \mathrm{C}$ for (a) $400 \mathrm{~h}$ and (b) $1200 \mathrm{~h}$.

When the process temperature is increased to $300^{\circ} \mathrm{C}$, an intermetallic bonding zone with a very small number of defects is obtained, as shown in Fig. $8 \mathrm{c}$ and d. Valleys between single $\mathrm{Ni}_{3} \mathrm{Sn}_{4}$ needles are filled with $\mathrm{Ag}_{3} \mathrm{Sn}$ IMC. Small amounts of small submicron-sized defects can be observed within the $\mathrm{Ni}_{3} \mathrm{Sn}_{4}$ layer only.

However, further increase of the process temperature to $350^{\circ} \mathrm{C}$ clearly results in more defects, as illustrated in Fig. 8e and f. Pores of size of up to $2 \mu \mathrm{m}$ form predominantly within the $\mathrm{Ni}_{3} \mathrm{Sn}_{4}$ layer; a 

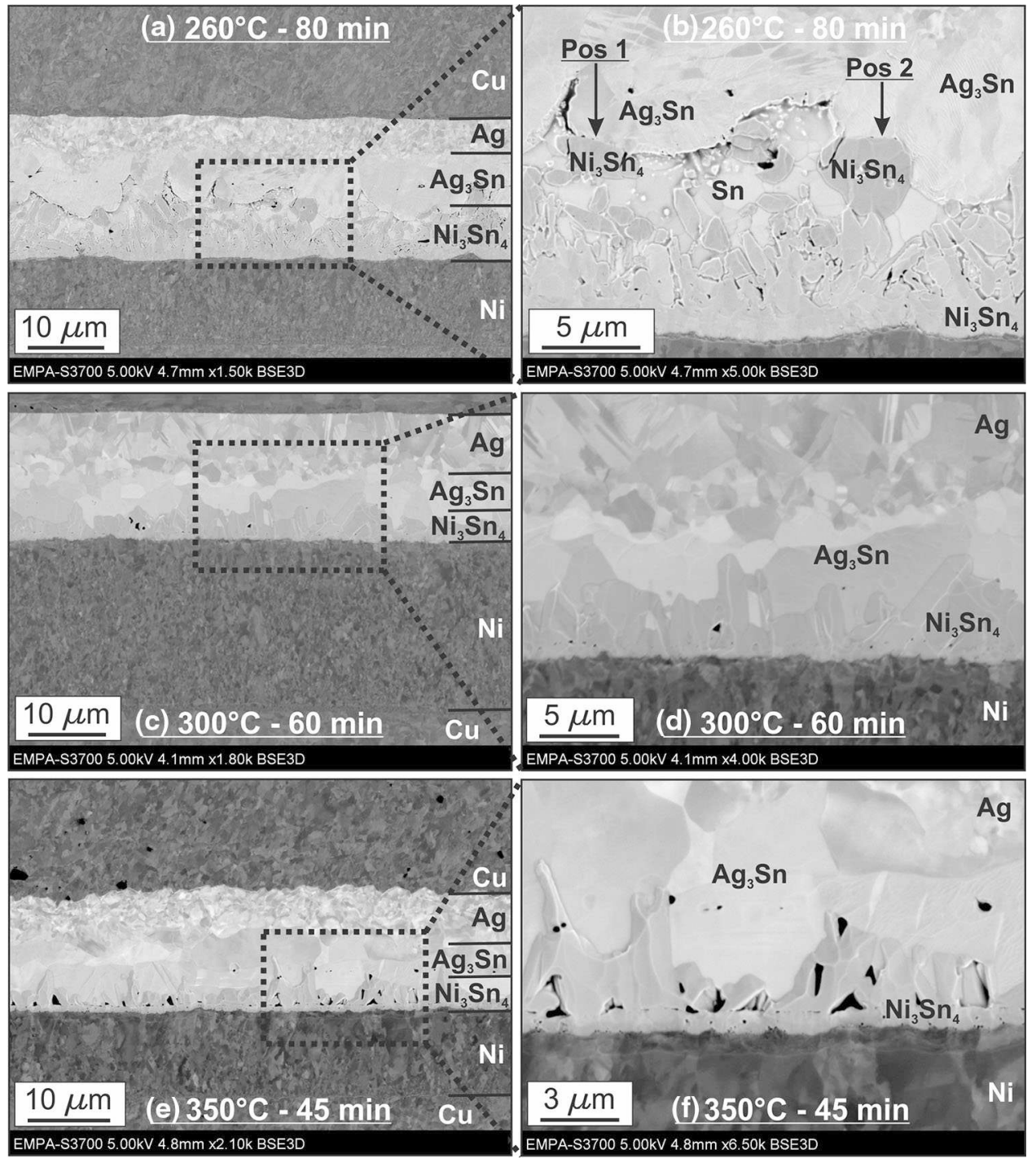

Fig. 8. TLP bonding of samples $\mathrm{C}$ at (a) $260^{\circ} \mathrm{C}$, (c) $300^{\circ} \mathrm{C}$, (e) $350^{\circ} \mathrm{C}$, and, with higher magnification, in (b), (d), and (f).

smaller amount of smaller pores of size $<1 \mu \mathrm{m}$ occurs within the $\mathrm{Ag}_{3} \mathrm{Sn}$ IMC layer.

Shear tests on samples C, TLP bonded at $300^{\circ} \mathrm{C}$, resulted in a mean shear strength of $40.7 \pm$ 13.7 MPa. The brittle fracture behavior is dominated by the $\mathrm{Ni}_{3} \mathrm{Sn}_{4}$ IMC, and crack propagation mainly occurs within the $\mathrm{Ni}_{3} \mathrm{Sn}_{4}$ layer, where pores are mainly expected. However, the fracture surface in Fig. 9 also shows that failure can occur along the $\mathrm{Ag}_{3} \mathrm{Sn}-\mathrm{Ni}_{3} \mathrm{Sn}_{4}$ interface when $\mathrm{Ag}_{3} \mathrm{Sn}$ scallops are visible. The shear strength is between those obtained for samples A and B. Although failure appears in the $\mathrm{Ni}_{3} \mathrm{Sn}_{4}$ layer for samples $\mathrm{B}$ and $\mathrm{C}$ (predominantly), the much smaller number of defects in samples $\mathrm{C}$ leads to the increase of shear strength.

\section{Phase Formation During Annealing}

Annealing experiments were conducted on samples $\mathrm{C}$ with combined IMC layers $\mathrm{Ag}-\mathrm{Ag}_{3} \mathrm{Sn}-$

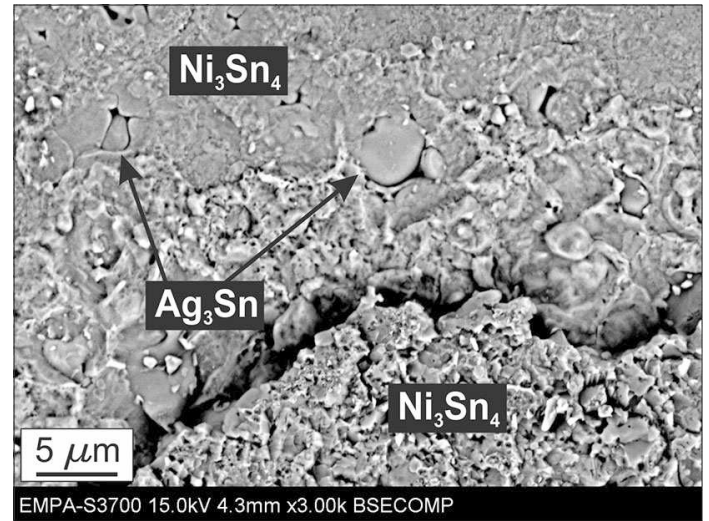

Fig. 9. Top view on fracture surface of samples $C$.

$\mathrm{Ni}_{3} \mathrm{Sn}_{4}-\mathrm{Ni}$ which were TLP bonded at $300^{\circ} \mathrm{C}$ for $60 \mathrm{~min}$, on the basis of investigations reported in the section "Phase Formation During TLP 
Bonding". Changes in microstructure were monitored during annealing at $200^{\circ} \mathrm{C}$ when, after $400 \mathrm{~h}$, $\mathrm{Ag}_{3} \mathrm{Sn}$ IMC was already transformed into $\mathrm{Ag}-\mathrm{Sn}$ solid solution and a more or less planar layer of $\mathrm{Ni}_{3} \mathrm{Sn}_{4}$ formed. The $\mathrm{Ag}$ layer contained 6 at.\% $\mathrm{Sn}$. Interestingly, the microstructure did not change further when the samples were annealed for $1200 \mathrm{~h}$, as shown in Fig. 10a

Annealing at $300^{\circ} \mathrm{C}$ for $400 \mathrm{~h}$ led to formation of $(\mathrm{Ni}, \mathrm{Cu})_{3} \mathrm{Sn} \mathrm{IMC}$ containing 55 at.\% Ni, 12 at.\% $\mathrm{Cu}$, and 33 at.\% Sn. $\mathrm{Cu}$ was again provided by diffusion from the substrate through the $\mathrm{Ag}$ layer. $\mathrm{Ag}_{3} \mathrm{Sn}$ IMC was not found in the joint. Longer annealing time up to $1200 \mathrm{~h}$ did not further affect the microstructure and the chemical phase composition within the samples, as illustrated in Fig. 10b. However, the transformations at $300^{\circ} \mathrm{C}$ were accompanied by formation of pores within the IMC layer and at the $(\mathrm{Ni}, \mathrm{Cu})_{3} \mathrm{Sn}-\mathrm{Ni}$ and $(\mathrm{Ni}, \mathrm{Cu})_{3} \mathrm{Sn}-\mathrm{Ag}$ interfaces.

\section{DISCUSSION}

\section{Mechanisms of Defect Formation During TLP Bonding}

TLP bonding of samples $\mathrm{A}, \mathrm{B}$, and $\mathrm{C}$ with different interlayer combinations revealed that the process temperature has a significant effect on the microstructure of the joint, in particular the number, size, and position of pores. Irrespective of the interlayer system, an ideal process temperature of approximately $300^{\circ} \mathrm{C}$ was identified. At this temperature the number of pores was minimized and

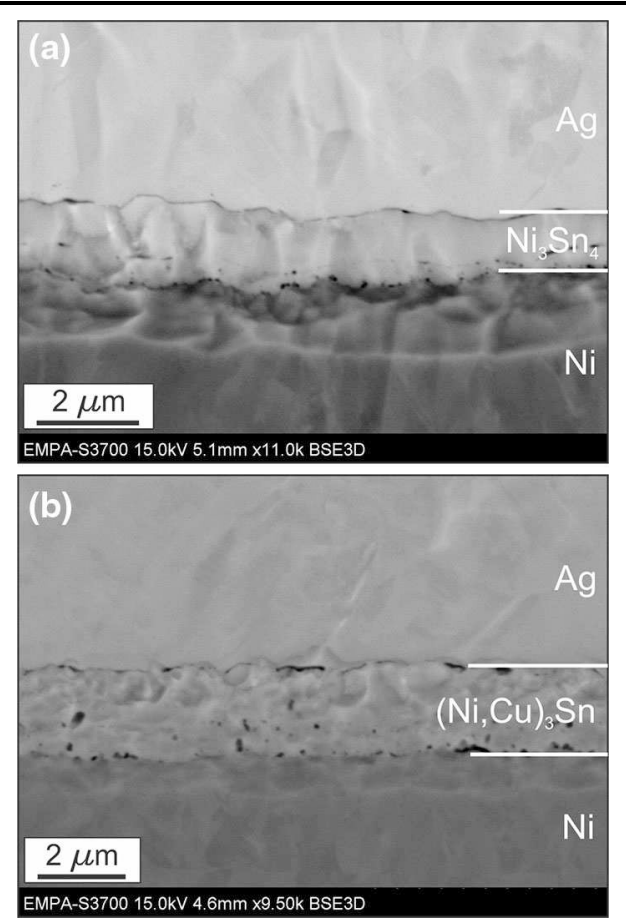

Fig. 10. TLP bonded microstructure with $\mathrm{Ag}-\mathrm{Ag}_{3} \mathrm{Sn}-\mathrm{Ni}_{3} \mathrm{Sn}_{4}-\mathrm{Ni}$ after annealing for $1200 \mathrm{~h}$ at (a) $200^{\circ} \mathrm{C}$ and (b) $300^{\circ} \mathrm{C}$. the reaction kinetics were maximized, resulting in the most efficient joining process.

In our previous work on the formation of $\mathrm{Ag}_{3} \mathrm{Sn}$ IMC ${ }^{15}$ we proved that the root-mean-square (RMS) roughness of the scallop-like $\mathrm{Ag}_{3} \mathrm{Sn}$ IMC growing toward the liquid Sn phase increases with higher holding temperature. Scallops become broader and more irregular. During TLP bonding, scallops symmetrically nucleate at both Ag-Sn interfaces and propagate into the liquid $\mathrm{Sn}$. After a specific time, both growth front lines meet and leave behind entrapped Sn islands in the center of the joint which are isothermally transformed into $\mathrm{Ag}_{3} \mathrm{Sn}$ IMC. Equation 4 shows the reactions from incomplete to complete IMC transformation:

$$
3 \mathrm{Ag}+\mathrm{Sn}+\mathrm{Ag}_{3} \mathrm{Sn} \rightarrow 2 \mathrm{Ag}_{3} \mathrm{Sn} \Rightarrow 3 \mathrm{Ag}+\mathrm{Sn} \rightarrow \mathrm{Ag}_{3} \mathrm{Sn}
$$

When mass conservation is considered, the volume difference $\Delta V$ between IMC and base materials can be obtained from:

$$
\Delta V=1-\frac{1 M\left(\mathrm{Ag}_{3} \mathrm{Sn}\right) / \rho\left(\mathrm{Ag}_{3} \mathrm{Sn}\right)}{3 M(\mathrm{Ag}) / \rho(\mathrm{Ag})+1 M(\mathrm{Sn}) / \rho(\mathrm{Sn})}
$$

According to Eq. 5, the transformation process leads to volume contraction of approximately $9 \mathrm{vol} . \%$ and the probability of shrinkage porosity is expected to increase when the remaining Sn islands are large. Because of the temperature-dependent morphology of the $\mathrm{Ag}_{3} \mathrm{Sn}$ scallops, the size of the Sn islands will increase when higher process temperatures are used. The process of defect formation during TLP bonding with $\mathrm{Ag}-\mathrm{Sn}-\mathrm{Ag}$ interlayers is shown schematically for a process temperature $T_{1}$ in Fig. 11a and b and for $T_{2}\left(>T_{1}\right)$ in Fig. 11c and d. This model is in good agreement with the experimental observations in Fig. 2, when massive scallops grew at $350^{\circ} \mathrm{C}$ after $1 \mathrm{~min}$ (Fig. 2c) whereas more but smaller scallops nucleated at $300^{\circ} \mathrm{C}$ after 1 min (Fig. 2a). Higher process temperature resulted in a flawed TLP joint (Fig. 2d), and reducing the temperature by $50^{\circ} \mathrm{C}$ led to only sporadic development of submicron-sized pores (Fig. 2b). As predicted by the model, pores form within the $\mathrm{Ag}_{3} \mathrm{Sn}$ IMC layer in which scallops growing from both sides impinge.

The model for formation of shrinkage porosity in samples A was further confirmed by means of an additional TLP experiment at $320^{\circ} \mathrm{C}$ with a dwell time of $20 \mathrm{~min}$. Figure 12 shows the microstructure of this joint when the TLP process is incomplete, yet as it could be estimated by use of Eq. 1. At this late reaction stage, randomly distributed Sn entrapments can be seen within the IMC layer. The magnified view of one of these Sn islands in Fig. 12b reveals that pores can form as a result of different specific volumes of $\mathrm{Sn}$ and $\mathrm{Ag}_{3} \mathrm{Sn}$. Bosco's model ${ }^{31}$ of defect formation during TLP bonding with $\mathrm{Cu}-\mathrm{Sn}-$ $\mathrm{Cu}$ interlayers cannot be used for our joining con- 

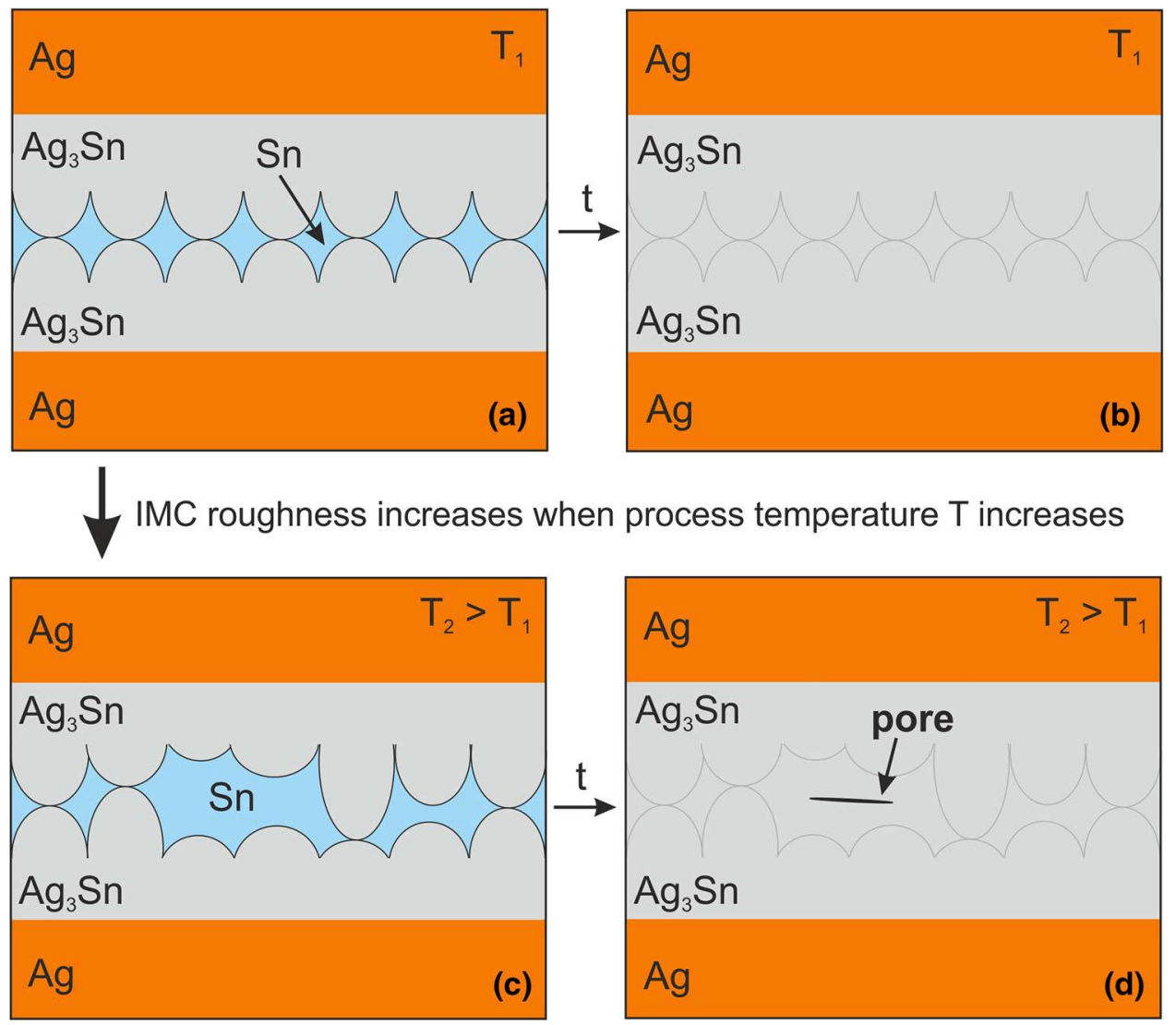

Fig. 11. Schematic diagram of TLP bonding by use of Ag-Sn-Ag interlayers, with intermediate step and after full transformation into IMC at $T_{1}$ in (a) and (b) and at $T_{2}>T_{1}$ in (c) and (d).

figuration, because the issue of solid-state IMC formation was effectively bypassed by using Sn foil instead of coatings. Bosco identified Sn coating thickness and heating rate as crucial factors, and our work extends this concept and introduces process temperature as having a major effect on the microstructure of TLP bonded joints.

The porosity of TLP bonded samples B with Ni$\mathrm{Sn}-\mathrm{Ni}$ interlayers can be deduced from a volume contraction of approximately 11 vol.\% when Eqs. 4 and 5 are applied to $\mathrm{Ni}_{3} \mathrm{Sn}_{4}$ IMC formation. This is in good agreement with the value obtained in Ref. 34 when void formation in the Ni-Sn system under solid-state conditions was correlated with shrinkage effects. At processing temperatures of $260^{\circ} \mathrm{C}$ and $300^{\circ} \mathrm{C}$, pores only appear in two defect planes at a defined distance from the Ni layers. This effect is a result of the morphological characteristics of $\mathrm{Ni}_{3} \mathrm{Sn}_{4}$ IMC growth. ${ }^{8,9,36}$ After nucleation, needle-like $\mathrm{Ni}_{3} \mathrm{Sn}_{4}$ IMC grains grow from the liquid, as shown in Fig. 13a. Ni can dissolve in the liquid Sn, because the IMC layer is not dense and intimate contact points between $\mathrm{Ni}$ and liquid $\mathrm{Sn}$ provide fast diffusion paths. Because of needle growth in the length and width directions, the IMC layer at the $\mathrm{Ni}$ interface densifies and becomes detached, and more or less equiaxed $\mathrm{Ni}_{3} \mathrm{Sn}_{4}$ IMC particles nucleate within the liquid $\mathrm{Sn}$, as shown schematically in
Fig. 13b. Persistent diffusion of Ni into the liquid $\mathrm{Sn}$ through the $\mathrm{Ni}_{3} \mathrm{Sn}_{4}$ IMC layer leads to coalescence of the $\mathrm{Ni}_{3} \mathrm{Sn}_{4}$ particles, and $\mathrm{Sn}$ islands form ahead of the needle-like IMC. Shrinkage porosity occurs and leaves defect planes behind, as observed experimentally. The final process step, with full transformation into the IMC, is shown schematically in Fig. $13 \mathrm{c}$. At $350^{\circ} \mathrm{C}$, large defects also appear along the center of the joint, probably because of very irregular growth of the detached $\mathrm{Ni}_{3} \mathrm{Sn}_{4}$ particles and formation of Sn entrapments. The number of pores in samples B could be reduced by choosing a process temperatures below $300^{\circ} \mathrm{C}$ but (nearly) defect free TLP joints could not be achieved, in contrast with samples A. Growth of detached $\mathrm{Ni}_{3} \mathrm{Sn}_{4}$ IMC can certainly be avoided by using much thinner Sn foil (approx. $2 \mu \mathrm{m}$ ). Handling of such thin foil is, however, very difficult.

In contrast with samples $\mathrm{A}$ and $\mathrm{B}$, for which a lower process temperature led to better joints, a narrow temperature range at approximately $300^{\circ} \mathrm{C}$ was identified for samples $\mathrm{C}$ with combined layers of $\mathrm{Ag}-\mathrm{Sn}-\mathrm{Ni}$ in which a nearly defect-free microstructure was obtained. $\mathrm{Ag}_{3} \mathrm{Sn}$ IMC fill the valleys of $\mathrm{Ni}_{3} \mathrm{Sn}_{4}$ needles, as is apparent in Fig. 8c and d. Formation of two neighboring IMC layers is different from the morphology suggested in the patent by Chang, ${ }^{35}$ in which the second intermetallic phase is 
supposed to be fully integrated within the first intermetallic phase. Single small pores can be found only within the $\mathrm{Ni}_{3} \mathrm{Sn}_{4}$ layer. At $350^{\circ} \mathrm{C}$, the position of most of the pores is identical but their size and number increase substantially because of more irregular growth of the IMC needles and shrinkage porosity (Fig. 6e and f). At a lower temperature,

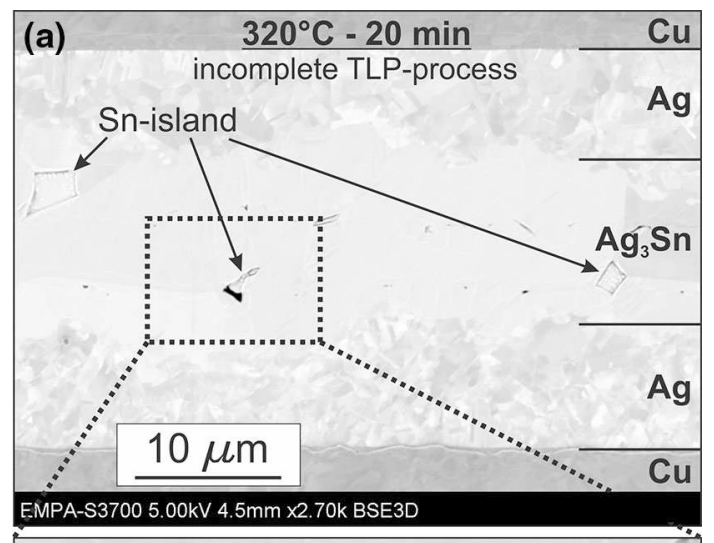

(b)

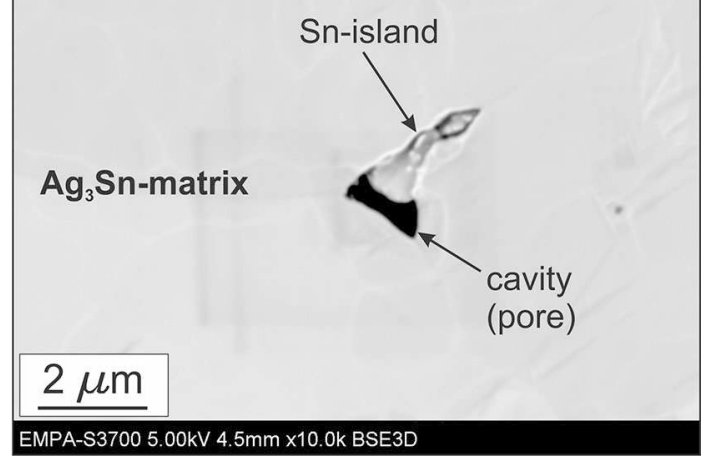

Fig. 12. (a) Entrapped $\mathrm{Sn}$ islands after incomplete TLP process with $\mathrm{Ag}-\mathrm{Sn}-\mathrm{Ag}$ interlayers, (b) pore formation from $\mathrm{Sn}$ island. $260^{\circ} \mathrm{C}$, process kinetics, of the $\mathrm{Ag}_{3} \mathrm{Sn}$ IMC scallops in particular, are too slow to meet the $\mathrm{Ni}_{3} \mathrm{Sn}_{4}$ IMC needles before the detached $\mathrm{Ni}_{3} \mathrm{Sn}_{4}$ particles nucleate as shown in Fig. 13. These particles act as obstacles to the scallops, as indicated by Pos. 1 and 2 in Fig. 8b. Consequently, after 80 min dwell time (sufficient when kinetics for the individual systems $\mathrm{Ag}-\mathrm{Sn}$ and Ni-Sn are considered), a large volume of $\mathrm{Sn}$ is still left in the system. Besides very slow kinetics, the TLP joint is expected to result in a large number of defects after full transformation into IMC. It is essential for homogeneous and defect-free TLP joints to have a second intermetallic phase, here $\mathrm{Ag}_{3} \mathrm{Sn}$, with sufficiently rapid kinetics to prevent the detached $\mathrm{Ni}_{3} \mathrm{Sn}_{4}$ IMC from nucleation.

In general, the volume of the entrapped Sn islands is related to coarsening and the interfacial roughness (i.e. irregularity) of the IMC forming within the liquid Sn layer. Because both increase with increasing temperature and time, the process can be adjusted to achieve void reduction. In this study the threshold value for temperature was found experimentally to be $300^{\circ} \mathrm{C}$, but it can be strongly assumed that thinner Sn foil (faster process time) will also lead to fewer defects within the IMC layer.

\section{Thermal Stability of TLP-Bonded Microstruc- tures}

As documented by Bosco et al. ${ }^{32}$ and Gollas et al., ${ }^{33}$ TLP bonded systems tend to transform toward phases with a higher proportion of the highmelting-point material, i.e. $\mathrm{Ag}, \mathrm{Ni}$, or $\mathrm{Cu}$, and finally into solid solution during heat treatment. Our work showed that the required mobility of atoms is not sufficiently high at $200^{\circ} \mathrm{C}$ and the microstructures hardly change in binary interlayer systems after long-term annealing up to $1200 \mathrm{~h}$. Thus, TLP bonding is a promising technique for chip packaging
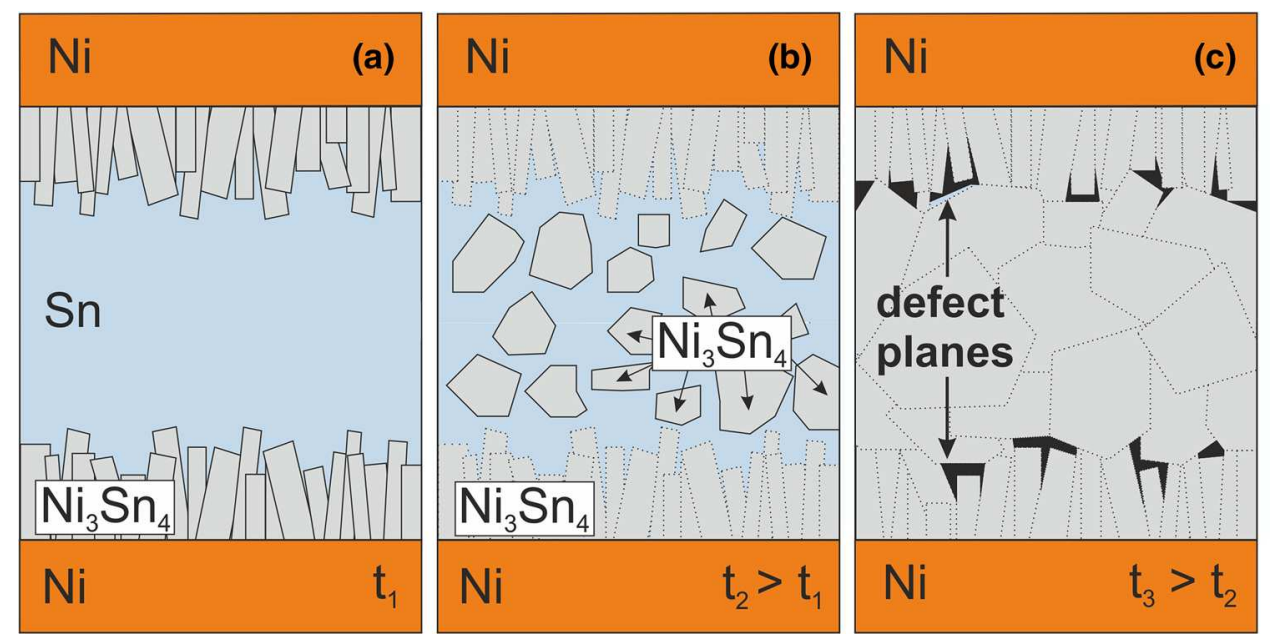

Fig. 13. Schematic diagram of TLP bonding using Ni-Sn-Ni interlayers: (a) early stage after $t_{1}$, (b) intermediate stage after $t_{2}>t_{1}$ and (c) after full transformation into IMC after $t_{3}>t_{2}$. 
applications when peak temperatures up to $175^{\circ} \mathrm{C}$ are applied. Because the microstructure is stable, mechanical, thermal, and electrical properties will not change during operation (unless as a result of thermo-mechanical fatigue). In combined interlayers with adjacent $\mathrm{Ag}_{3} \mathrm{Sn}$ and $\mathrm{Ni}_{3} \mathrm{Sn}_{4}$ IMC, transformations are driven toward $\mathrm{Ni}_{3} \mathrm{Sn}_{4}$ IMC, as a result of the different enthalpy of formation, $\Delta H_{\mathrm{f}}$. $\mathrm{Ni}_{3} \mathrm{Sn}_{4} \quad$ IMC are energetically favored with $\Delta H_{\mathrm{f}}=-7.4 \mathrm{~kJ} / \mathrm{mol}_{\mathrm{Sn}}{ }^{37}$ compared with $\mathrm{Ag}_{3} \mathrm{Sn}$ with $\Delta H_{\mathrm{f}}=-4.2 \mathrm{~kJ} / \mathrm{mol}_{\mathrm{Sn}} \cdot{ }^{38}$ When transformation into a planar $\mathrm{Ni}_{3} \mathrm{Sn}_{4}$ layer is complete after $400 \mathrm{~h}$, the microstructure does not further change during longterm annealing. The remelting temperature of the joint is increased from $480^{\circ} \mathrm{C}\left(T_{\mathrm{m}, \mathrm{Ag}_{3} \mathrm{Sn}}\right)$ in the asbonded state to $794.5^{\circ} \mathrm{C}\left(T_{\mathrm{m}_{1} \mathrm{Ni}_{3} \mathrm{Sn}_{4}}\right)$ after annealing.

Annealing at $300^{\circ} \mathrm{C}$ can be used to adjust the characteristics of the microstructure of TLP-bonded components and to improve the properties of the joint. For samples A, two transformation processes overlap when the $\mathrm{Ag}_{3} \mathrm{Sn}$ IMC is converted into an $\mathrm{Ag}-\mathrm{Sn}$ solid solution and $\mathrm{Cu}_{3} \mathrm{Sn}$ particles form because of diffusion of $\mathrm{Cu}$ from the substrate material into the TLP system. Elongated $\mathrm{Cu}_{3} \mathrm{Sn}$ precipitates evolve randomly within the $\mathrm{Ag}_{3} \mathrm{Sn}$ IMC layer and the $\mathrm{Ag}-\mathrm{Sn}$ solution along grain boundaries where $\mathrm{Cu}$ diffuses fastest. $\mathrm{Cu}_{3} \mathrm{Sn}$ IMC are energetically favored with a enthalpy of formation $\Delta H_{\mathrm{f}}=-8.2$ $\mathrm{kJ} / \mathrm{mol}_{\mathrm{Sn}}$ compared with the $\mathrm{Ag}_{3} \mathrm{Sn}$ IMC with $\Delta H_{\mathrm{f}}=-4.2 \mathrm{~kJ} / \mathrm{mol}_{\mathrm{Sn}} \cdot{ }^{38}$ Because $\mathrm{Ag}_{3} \mathrm{Sn}$ IMC and $\mathrm{Cu}_{3} \mathrm{Sn}$ both have an orthorhombic structure, $\mathrm{Cu}$ atoms can easily substitute $\mathrm{Ag}$ atoms in the crystal lattice. This effect could be avoided by depositing diffusion barriers consisting of, e.g., $\mathrm{Ni}$ or $\mathrm{W}$ between the $\mathrm{Cu}$ substrate and the $\mathrm{Ag}$ coating. After long-term annealing for $1200 \mathrm{~h}$, the transformation processes result in a microstructure of $\mathrm{Cu}_{3} \mathrm{Sn}$ particles embedded in a matrix of $\mathrm{Ag}-\mathrm{Sn}$ solid-solution, as shown in Fig. 4. It is important to mention that the initial interlayer thickness ratio of $\mathrm{Ag} / \mathrm{Sn}$ (3.5/1) was not sufficient to form Ag-Sn solid solution, which requires a ratio of at least $5.7 / 1$, so full transformation into $\mathrm{Ag}-\mathrm{Sn}$ solid solution was only enabled by simultaneous formation of $\mathrm{Cu}_{3} \mathrm{Sn}$. Because of the lack of $\mathrm{Ag}$, transformation into the $\mathrm{Ag}$ Sn solid solution requires much more time than reported by Gollas et al. ${ }^{33}$ when 480 min at $320^{\circ} \mathrm{C}$ were sufficient. The remelting temperature of the joint is increased and limited by the melting point of $\mathrm{Cu}_{3} \mathrm{Sn}\left(676^{\circ} \mathrm{C}\right)$. It can be assumed that the thermal, electrical, and possibly mechanical properties of the joint are enhanced. Bosco et al. ${ }^{32}$ reported an increase of bending strength from $300 \mathrm{MPa}$ to $400 \mathrm{MPa}$ when they compared TLP bonded joints consisting of only $\mathrm{Cu}-\mathrm{Sn}$ IMC with a mixture of solid solution and IMC. However, this aspect might be subject of a follow-up project because this work focused mainly on microstructure.

Microstructure changes were also monitored for samples $\mathrm{B}$ with initial $\mathrm{Ni}-\mathrm{Ni}_{3} \mathrm{Sn}_{4}-\mathrm{Ni}$ interlayers. The transformations were in accordance with the binary $\mathrm{Ni}-\mathrm{Sn}$ phase diagram, driven in the direction of the lowest enthalpy of formation when the $\mathrm{Ni}_{3} \mathrm{Sn}_{4}$ phase $\left(\Delta H_{\mathrm{f}}=-7.4 \mathrm{~kJ} / \mathrm{mol}_{\mathrm{Sn}}\right)$ is converted into $\mathrm{Ni}_{3} \mathrm{Sn}_{2}$ $\left(\Delta H_{\mathrm{f}}=-17.5 \mathrm{~kJ} / \mathrm{mol}_{\mathrm{Sn}}\right)$ and subsequently into $\mathrm{Ni}_{3} \mathrm{Sn}$ $\left(\Delta H_{\mathrm{f}}=-21 \mathrm{~kJ} / \mathrm{mol}_{\mathrm{Sn}}\right){ }^{37}$ The phase transformations depend on diffusion of $\mathrm{Ni}$ into the Ni-Sn IMC; at $300^{\circ} \mathrm{C}$ this is too slow for full transformation into the final $\mathrm{Ni}_{3} \mathrm{Sn}$ phase after $1200 \mathrm{~h}$. A layered structure consisting of $\mathrm{Ni}_{3} \mathrm{Sn} \quad\left(T_{\mathrm{m}_{\mathrm{Ni}} \mathrm{Sn}}=1174^{\circ} \mathrm{C}\right), \quad \mathrm{Ni}_{3} \mathrm{Sn}_{2}$ $\left(T_{\mathrm{m}, \mathrm{Ni}_{3} \mathrm{Sn}_{2}}=1264^{\circ} \mathrm{C}\right)$ and $\mathrm{Ni}_{3} \mathrm{Sn}_{4}\left(T_{\mathrm{m}_{\mathrm{Ni}} \mathrm{Ni}_{3} \mathrm{Sn}_{4}}=794.5^{\circ} \mathrm{C}\right)$ was obtained after annealing for $1200 \mathrm{~h}$, as shown in Fig. 7b, because in the Ni-Sn system solubility of $\mathrm{Sn}$ atoms in the Ni lattice is only very low. Partial phase transformations within the TLP joint occur in the volume where pores are formed after TLP bonding. After transformation, the size of these pores is substantially reduced which can be related to volume expansion of 6 vol.\% for $\mathrm{Ni}_{3} \mathrm{Sn}_{4} \rightarrow \mathrm{Ni}_{3} \mathrm{Sn}_{2}$ and 3 vol.\% for $\mathrm{Ni}_{3} \mathrm{Sn}_{2} \rightarrow \mathrm{Ni}_{3} \mathrm{Sn}$. This expansion works opposite to the volume contraction described in the section "Mechanisms for Defect Formation During TLP Bonding", which accounts for shrinkage porosity during TLP bonding. The Ni coating effectively prevented $\mathrm{Cu}$ from diffusion into the TLP joint.

Annealing of combined interlayers is affected by diffusion of $\mathrm{Cu}$ through the $\mathrm{Ag}$ layer so that intermixing leads to formation of $(\mathrm{Ni}, \mathrm{Cu})_{3} \mathrm{Sn}$ IMC after $400 \mathrm{~h}$. Because no further changes of the microstructure were observed during long-term annealing up to $1200 \mathrm{~h}$, it can be assumed that the configuration is stable against service temperatures of $300^{\circ} \mathrm{C}$. Slight degradation of the microstructure was observed for samples $\mathrm{C}$ annealed at $300^{\circ} \mathrm{C}$ when the transformations led to formation of pores within the IMC layer and between IMC and base metallization, which may weaken the structural integrity of these joints. It is noteworthy that formation of $(\mathrm{Ni}, \mathrm{Cu})_{3} \mathrm{Sn} \mathrm{IMC}$ and possibly pores could be suppressed by use of diffusion barriers between the $\mathrm{Cu}$ substrate and the $\mathrm{Ag}$ coating. Observations of phase transformations during annealing in this work might be useful for the studies reported in Refs. 34 and 35 with TLP joints consisting of different IMC in intimate contact.

\section{CONCLUSIONS}

This work chose an approach in which $\mathrm{Cu}$ substrates were TLP bonded with $\mathrm{Ag}-\mathrm{Sn}-\mathrm{Ag}, \mathrm{Ni}-\mathrm{Sn}-$ $\mathrm{Ni}$, and combined Ag-Sn-Ni interlayers. Because the CTE mismatch was kept low, characteristics of the TLP process and the mechanical and thermal behavior of TLP bonded components could be investigated without significant interference from thermally induced residual stresses. The following scientific conclusions were derived.

1. The optimum process temperature was $300^{\circ} \mathrm{C}$ for all three interlayer systems; at this temperature the number of pores is minimized and the process efficiency (IMC growth rate) is high. 
2. It was verified experimentally that the mechanisms of pore formation were related to volume contraction (shrinkage porosity) during isothermal solidification from liquid Sn into IMC. Different defect positions and amounts were ascribed to the specific IMC growth characteristics of each interlayer system.

3. Mechanical shear strength was shown to be highest for samples $\mathrm{A}\left(\mathrm{Ag}-\mathrm{Ag}_{3} \mathrm{Sn}-\mathrm{Ag}\right)$ and $\mathrm{C}$ $\left(\mathrm{Ag}-\mathrm{Ag}_{3} \mathrm{Sn}-\mathrm{Ni}_{3} \mathrm{Sn}_{4}-\mathrm{Ni}\right), \quad 60.4 \mathrm{MPa}$ and $40.7 \mathrm{MPa}$, respectively, and lowest for samples $\mathrm{B}\left(\mathrm{Ni}-\mathrm{Ni}_{3} \mathrm{Sn}_{4}-\mathrm{Ni}\right), 27.4 \mathrm{MPa}$. Crack propagation occurred within the IMC layer where pores weaken the structural integrity. Ductile fracture features were identified within $\mathrm{Ag}_{3} \mathrm{Sn}$ IMC whereas $\mathrm{Ni}_{3} \mathrm{Sn}_{4}$ IMC fracture was purely brittle.

4. Long-term annealing at $200^{\circ} \mathrm{C}$ resulted in binary TLP bonded systems with very good microstructure stability. At $300^{\circ} \mathrm{C}$, IMC phases transform toward Ag-Sn solid solution (from $\mathrm{Ag}_{3} \mathrm{Sn}$ ) and $\mathrm{Ni}_{3} \mathrm{Sn}$ (from $\mathrm{Ni}_{3} \mathrm{Sn}_{4}$ ). $\mathrm{Cu}$ diffuses into $\mathrm{Ag}$ along grain boundaries and forms regularly distributed $\mathrm{Cu}_{3} \mathrm{Sn}$ precipitates. Combined IMC interlayers in samples $\mathrm{C}$ transform toward Ni-based IMC at $200^{\circ} \mathrm{C}$ and $300^{\circ} \mathrm{C}$. $\mathrm{Ag}-$ $\mathrm{Sn}-\mathrm{Ag}$ and Ni-Sn-Ni TLP systems are suitable for service temperatures up to $300^{\circ} \mathrm{C}$ without any degradation of microstructure. Combined interlayers with the $\mathrm{Ag}-\mathrm{Sn}-\mathrm{Ni}$ stacking sequence are recommended for service up to $200^{\circ} \mathrm{C}$, because pore formation occurs during annealing at $300^{\circ} \mathrm{C}$.

\section{ACKNOWLEDGEMENT}

The authors gratefully acknowledge ABB Corporate Research Switzerland for financing this study and, in particular, Dr. Slavo Kicin for his support.

\section{REFERENCES}

1. B.J. Baliga, IEEE Electr. Device L. 10, 455 (1989).

2. M. Willander, M. Friesel, Q.U. Wahab, and B. Straumal, J. Mater. Sci. 17, 1 (2006).

3. G.O. Cook and C.D. Sorensen, J. Mater. Sci. 46, 5305 (2011).

4. R. Labie, W. Ruythooren, and J. Van Humbeeck, Intermetallics 15, 396 (2007).

5. M.S. Park and R. Arroyave, Acta Mater. 58, 4900 (2010).

6. M. Schaefer, R.A. Fournelle, and J. Liang, J. Electron. Mater. 27, 1167 (1998).

7. A.C.K. So, Y.C. Chan, and J.K.L. Lai, IEEE T. Compon. Pack B 20, 161 (1997).
8. S. Bader, W. Gust, and H. Hieber, Acta Metall. Mater. 43, 329 (1995).

9. J. Gorlich, D. Baither, and G. Schmitz, Acta Mater. 58, 3187 (2010).

10. D. Gur and M. Bamberger, Acta Mater. 46, 4917 (1998).

11. Y.W. Lin and K.L. Lin, J. Appl. Phys. 108, 063536 (2010).

12. J.O. Suh, K.N. Tu, A.T. Wu, and N. Tamura, J. Appl. Phys. 109, 123513 (2011).

13. M.L. Huang, F. Yang, N. Zhao, and Y.C. Yang, J. Alloy. Compd. 602, 281 (2014).

14. J.F. Li, P.A. Agyakwa, and C.M. Johnson, Acta Mater. 58, 3429 (2010).

15. A. Lis, M.S. Park, R. Arroyave, and C. Leinenbach, J. Alloy. Compd. 617, 763 (2014).

16. Z. Marinkovic and V. Simic, Thin Solid Films 195, 127 (1991).

17. S.K. Sen, A. Ghorai, A.K. Bandyopadhyay, and S. Sen, Thin Solid Films 155, 243 (1987).

18. K. Suzuki, S. Kano, M. Kajihara, N. Kurokawa, and K. Sakamoto, Mater. Trans. 46, 969 (2005).

19. J.C. Lin, L.W. Huang, G.Y. Jang, and S.L. Lee, Thin Solid Films 410, 212 (2002).

20. Y.M. Liu, Y.L. Chen, and T.H. Chuang, J. Electron. Mater. 29, 1047 (2000).

21. Y.M. Liu and T.H. Chuang, J. Electron. Mater. 29, 405 (2000)

22. M. Millares, B. Pieraggi, and E. Lelievre, Scripta Metall. Mater. 27, 1777 (1992).

23. R. Roy and S.K. Sen, Thin Solid Films 197, 303 (1991).

24. J.S. Kim, T. Yokozuka, and C.C. Lee, Mat. Sci. Eng. AStruct. 458, 116 (2007).

25. J.F. Li, P.A. Agyakwa, and C.M. Johnson, J. Electron. Mater. 43, 983 (2014).

26. P.J. Wang, J.S. Kim, and C.C. Lee, in 12th IEEE International Symposium on Advanced Packaging Materials: Processes, Properties, and Interface (2007). doi:10.1109/ISAPM. 2007.4419926 .

27. T. Takahashi, S. Komatsu, and T. Kono, Electrochem. Solid St. 12, H263 (2009).

28. T.A. Tollefsen, A. Larsson, M.M.V. Taklo, A. Neels, X. Maeder, K. Hoydalsvik, D.W. Breiby, and K. Aasmundtveit, Metall. Mater. Trans. B 44, 406 (2013).

29. S.H. Eo, D.S. Kim, H.J. Jeong, and J.H. Jang, Electron. Mater. Lett. 9, 787 (2013).

30. B. Grummel, H.A. Mustain, Z.J. Shen, and A.R. Hefner, Proc. Int. Symp. Power (2011) 260.

31. N.S. Bosco and F.W. Zok, Acta Mater. 52, 2965 (2004).

32. N.S. Bosco and F.W. Zok, Acta Mater. 53, 2019 (2005).

33. B. Gollas, J.H. Albering, K. Schmut, V. Pointner, R. Herber, and J. Etzkorn, Intermetallics 16, 962 (2008).

34. H.Y. Chuang, J.J. Yu, M.S. Kuo, H.M. Tong, and C.R. Kao, Scripta Mater. 66, 171 (2012).

35. J.Y. Chang, T.C. Chang, T.H. Chuang, and C.Y. Lee, Dualphase intermetallic interconnection structure and method of fabricating the same, US Patent, US8742600B2, 2014.

36. A. Lis, C. Kenel, and C. Leinenbach, Empa - Swiss Federal Laboratories for Materials Science and Technology, $\mathrm{CH}-$ 8600 Duebendorf, submitted for publication (2015).

37. G.P. Vassilev, K.I. Lilova, and J.C. Gachon, Thermochim. Acta 447, 106 (2006).

38. H. Flandorfer, U. Saeed, C. Luef, A. Sabbar, and H. Ipser, Thermochim. Acta 459, 34 (2007). 